\title{
PENGARUH PENGAWASAN TERHADAP KINERJA PEGAWAI DALAM MENINGKATKAN PELAYANAN KESEHATAN DI KOTA PALU PROVINSI SULAWESI TENGAH
}

\author{
Ahmad Averus dan Andi Pitono \\ Prodi Kebijakan Pemerintahan Daerah Fakultas Politik Pemerintahan \\ Institut Pendidikan Dalam Negeri Kampus Jakarta dan Jatinangor \\ E-mail :ahmad averus@yahoo.co.id
}

\begin{abstract}
ABSTRAK. Rumah sakit sebagai salah satu elemen penting dalam pelayanan publik di bidang kesehatan. Adanya dorongan kemandirian dan persaingan mengakibatkan pelayanan kesehatan ini semakin terasa mahal bagi masyarakat, tidak terkecuali pelayanan rawat inap yang belum memenuhi harapan. Kondisi ini bila terus terjadi dapat berakibat pada pembangunan kualitas sumber daya manusia yang semakin melorot disebabkan oleh keberadaan rumah sakit yang seyogianya menjadi solusi bagi pelayanan kesehatan khususnya rawat inap tapi justru menjadi bagian dari permasalahan pelayanan kesehatan itu sendiri. Tujuan penelitian ini adalah untuk mengetahui pelaksanaan pengawasan terhadap kinerja dalam meningkatkan pelaksanaan pelayanan kesehatan rawat inap di rumah sakit umum. Adapun teori yang digunakan adalah teori pengawasan yang dikemukakan oleh Siagian, sedangkan teori kinerja dikutip dari Prawirosentono, dan teori pelayanan yang disampaikan oleh Sabarguna. Metode penelitian yang digunakan adalah metode kuantitatif, serta analisis korelasi productmoment, determinasi dan koefisien korelasi untuk mengetahui pengaruh pengawasan terhadap kinerja perawat dalam meningkatkan pelayanan kesehatan rawat inap di rumah sakit. Hasil penelitian ini menunjukan bahwa pengawasan pimpinan rumah sakit berpengaruh terhadap kinerja perawat, namun kinerja perawat kurang berpengaruh terhadap kualitas pelayanan kesehatan rawat inap, ini karenakan para perawat masih mengerjakan tugas lain diluar tugas utama mereka. Penelitian ini diharapkan dapat memberikan kontribusi yang berkaitan dengan administrasi di rumah sakit khususnya mengenai pelaksanaan pengawasan dan pengaruhnya terhadap kinerja perawat dalam memberikan pelayanan kesehatan rawat inap yang terbaik kepada para pasien.
\end{abstract}

Kata kunci: Pengawasan, Kinerja, Pelayanan

\section{THE EFFECTS OF SUPERVISION ON THE EMPLOYEES PERFORMANCE IN IMPROVING HEALTH SERVICE IN PALU CENTRAL SULAWESI PROVINCE}

\begin{abstract}
Hospital is one of key elements on health public service. With higher competition and independency among the sectors, yet health public service is expensive even for the basic service, such as overnight care. If this situation continues, it could reduce the quality of human resources and detain the human development despite the expectation that hospital presence, especially overnight can be the solution for public health problems. To gain more knowledge on this, we employ several grand theories: the supervision theory from Siagian; the working performance theory from Prawirosentono; and the public service theory from Sabarguna. Besides that, quantitive method with correlation analysis of product moment is also being used to look at more deeply on the effects of supervision on nurses' performance in improving the service of overnight care at the hospital. The results of research indicate that supervision of hospital leaders affect the performance of nurses, but the performance of nurses has little effect on the quality of inpatient health services, this is because the nurses are still doing other tasks outside their main tasks. it is expected that the findings of this research, regarding to the supervising implementation and its impacts, can help the hospital staffs to deliver the best service to the patients and improve their service quality as well as their administration.
\end{abstract}

Key words: Monitoring, Performance, Services.

\section{PENDAHULUAN}

Fungsi pelayanan kesehatan di rumah sakit umum pada hakekatnya lebih dari sekedar menyembuhkan penyakit pasien yang berobat di sana, rumah sakit umum juga memiliki fungsi yang tidak kalah pentingnya yakni menjaga dan menciptakan paradigma sehat bagi masyarakat. Selain pembentuk paradigma sehat bagi masyarakat, peran tersebut pada dewasa ini makin menonjol mengingat timbulnya perubahan-perubahan struktur demografis, perkembangan ilmu pengetahuan dan teknologi, perubahan struktur sosial masyarakat dan pelayanan yang lebih bermutu, ramah dan sanggup memenuhi kebutuhan mereka yang menuntut perubahan pola pelayanan kesehatan. Disamping menjalankan fungsi sosialnnya, rumah sakit umum tidak terlepas dari persaingan dalam memberikan pelayanan kesehatan. Menurut Ndraha (2008 : 50) bahwa pemerintah tidak boleh menolak untuk menyelesaikan suatu urusan dan tidak boleh menolak mendengarkan tuntutan setiap warga masyarakat dengan alasan apapun, apalagi masalah kesehatan yang merupakan hak, kebutuhan dasar dan tuntutan setiap orang. Sedangkan Menurut Napitupulu (2007:164), bahwa Pelayanan merupakan serangkaian kegiatan suatu proses pemenuhan kebutuhan orang lain secara lebih memuaskan berupa produk jasa dengan sejumlah ciri seperti tidak terwujud, cepat hilang, lebih dapat dirasakan daripada memilki, dan pelanggan lebih dapat berpartisispasi aktif dalam proses mengkonsumsi jasa tersebut".

Dikaitkan dengan semakin meningkatnya pertumbuhan penduduk maka pentingnya pelayanan 
kesehatan menjadi suatu keharusan bagi setiap rumah sakitumumuntukmengantisipasihal tersebut. Mengingat kesehatan masyarakat sangat penting untuk menuju masyarakat sejahtera, sebab masyarakat yang sehat akan mampu menopang pemerintah dalam pelaksanaan tugas-tugasnya. Salah satu pelayanan kesehatan di rumah sakit umum adalah rawat inap, pada rawat inap tersebut pegawai rumah sakit umum yang memegang peranan penting dalam melayani pasien rawat inap adalah perawat, sebab perawat berhubungan lebih intens dengan pasien rawat inap. Oleh sebab itu perawat yang menangani pasien rawat inap harus menyadari dengan sebaik-baiknya bahwa pelayanan kesehatan rawat inap merupakan suatu proses mempercepat penyembuhan dan pemulihan pasien sehingga harus dilayani secara fisik dan psikis.

Namunhinggasaatinipelayanan kesehatan terhadap pasien rawat inap masih terdapat hasil yang belum dapat memenuhi harapan pasien, dari informasi yang diperoleh bahwa masih rendahnya kualitas pelayanan dapat ditandai dari masih sering terjadi keterlambatan dalam penanganan pasien dan terkadang dalam menangani pasien yang membutuhkan pertolongan dengan tindakan yang sifatnya harus dilakukan dengan segera, akan tetapi pada kondisi demikian perawat rumah sakit umum masih lebih mengutamakan meminta jaminan biaya pelayanan kesehatan dan penanganan proses administrasi pada keluarga pasien atau kerabat pasien, hal lainnya bila berkaitan dengan proses administrasi bagi pasien yang akan rawat inap mengalami prosedur yang harus dilewati cenderung berbelit-belit serta sulit, sehingga cepat atau tidaknya proses administrasi untuk pelayanan kesehatan rawat inap dapat ditentukan oleh paviliun yang akan ditempati. Selain itu cepat atau tidaknya proses administrasi bagi pasien rawat inap juga ditentukan oleh kedekatan hubungan antara pasien atau keluarga pasien dengan pegawai rumah sakit umum. Disamping itu, masih kurangnya perawat rumah sakit umum memberikan informasi yang dibutuhkan pasien maupun keluarga pasien, dan dalam memberikan informasi masih sering dibarengi dengan rendahnya keramahan dari perawat rumah sakit umum terhadap pasien maupun keluarga pasien.

Berkenaan dengan hal tersebut, sehingga diketahui bahwa salah satu penyebab dari rendahnya pelayanan kesehatan rawat inap yang ada di rumah sakit umum merupakan dampak dari rendahnya kinerja pegawai yang menangani pelayanan kesehatan, baik pelayanan kesehatan yang dilakukan secara langsung oleh perawat maupun secara tidak langsung oleh pegawai administrasi. Dimana pelayanan kesehatan yang dilakukan secara langsung, merupakan pelayanan secara medik pada pasien yang dilakukan oleh pihak rumah sakit umum, sedangkan pelayanan kesehatan secara tidak langsung, yakni pelayanan non medik oleh pihak rumah sakit umum dengan melakukan pelayanan administrasi, ataupun pelayanan yang dihasilkan memiliki keterkaitan tidak langsung bagi proses penyembuhan pasien.

Masih rendahnya pelayanan kesehatan rawat inap bagi pasien, disebabkan masih rendahnya kinerja perawat rumah sakit umum dalam melaksanakan tugas, sehingga adanya suatu dugaan bahwa hal ini diakibatkan dari masih rendahnya pelaksanaan salah satu dari fungsi administasi, yakni pelaksanaan pengawasan yang dilakukan oleh pimpinan rumah sakit umum. Berdasarkan hasil observasi di lapangan, terlihat lemahnya pengawasan ditandai dari lemahnya teguran ataupun sangsi yang diberikan terhadap perawat yang lalai dalam melakukan pekerjaan, hal tersebut dapat disebabkan adanya pengaruh familiar yang berlebihan di lingkungan kerja, serta masih berlakunya faktor senioritas yang dalam hal ini apabila pelanggaran dilakukan oleh perawat yang memiliki tingkat senioritas yang tinggi maka belum adanya tindakan yang tegas, serta masih kurangnya pimpinan rumah sakit umum melakukan pengawasan secara langsung terhadap pegawai rumah sakit umum dalam melaksanakan pekerjaan. Sehingga dari lemahnya pengawasan tersebut dapat mempengaruhi pada laporan atas hasil pekerjaan yang hanya menyampaikan tentang hal-hal yang baik-baik saja.

Untuk itu, dalam pelaksanaan pelayanan kesehatan rawat inap yang dilakukan oleh perawat rumah sakit umum, memiliki hubungan dengan bagaimana pelaksanaan pekerjaan yang dilakukan oleh perawat rumah sakit umum, sehingga dengan pelaksanaan pekerjaan yang baik, diharapkan akan berdampak pada hasil pelayanan rawat inap kesehatan yang baik pula. Sebagai salah satu fungsi administrasi maka faktor pengawasan menjadi salah satu hal penting dalam menjalankan kegiatan administrasi di rumah sakit umum, sebab dengan adanya pengawasan maka kebijakan pimpinan maupun rencana yang telah disepakati dan ditetapkan diharapkan akan dapat tercapai dengan sebaikbaiknya. Dalam konteks ini pengawasan menjadi suatu hal yang turut menentukan keberhasilan pimpinan rumah sakit umum dalam menjaga pekerjaan yang dilaksanakan setiap perawat agar sesuai dengan kebijakan yang telah ditentukan. Dalam hal ini, pengawasan yang dilakukan oleh pimpinan rumah sakit umum bukan semata-mata untuk mencari kesalahan perawat, namun pengawasan dari pimpinan rumah sakit umum untuk memastikan bahwa kinerja perawat rumah sakit umum telah sesuai dengan ketentuan yang ada, yang selanjutnya diharapkan akan dapat mempengaruhi kualitas pelayanan kesehatan rawat inap terhadap setiap pasien yang berobat di rumah sakit umum. Berbagai permasalahan tersebut menjadi dasar dalam menentukan tujuan penelitian ini yaitu untuk mengetahui pelaksanaan pengawasan terhadap kinerja pegawai dalam meningkatkan pelaksanaan pelayanan kesehatan rawat inap di rumah sakit umum. Lebih lanjut penelitian ini diharapkan dapat memberikan kontribusi yang berkaitan dengan penyelenggaraan administrasi 
di rumah sakit khususnya mengenai pelaksanaan pengawasan dan pengaruhnya terhadap kinerja pegawai dalam memberikan pelayanan kesehatan rawat inap yang terbaik kepada para pasien, disamping itu diharapkan pula pada masa yang akan datang pelayanan kesehatan rawat inap dapat dilakukan tindakan fisik maupun psikis dengan penanganan yang terbaik, hal ini disebabkan rumah sakit umum merupakan pusat pelayanan kesehatan pada masyarakat, serta rumah sakit dapat semakin berperan aktif dalam menciptakan masyarakat sehat rohani sekaligus jasmani.

\section{Tinjauan Konseptual}

Variabel pengawasan diukur oleh Siagian (1989: 139) yang mengemukakan bahwa Proses pengawasan pada dasarnya dilaksanakan oleh administrasi dan managemen dengan mempergunakan dua macam teknik, yakni Pengawasan langsung (direct control) ialah apabila pimpinan organisasi mengadakan sendiri pengawasan terhadap kegiatan yang sedang dijalankan. Pengawasan langsung ini dapat berbentuk sebagai berikut (a) inspeksi langsung, (b) on-the-spot observation, (c) onthe-spot report. Yang sekaligus berarti pengambilan keputusan on-the-spot pula jika diperlukan. Akan tetapi karena banyaknya dan kompleksnya tugas-tugas seorang pimpinan - terutama dalam organisasi yang besar - seorang pimpinan tidak mungkin dapat selalu menjalankan pengawasan langsung itu. Karena itu sering pula ia harus melakukan pengawasan yang bersifat tidak langsung, dan Pengawasan tidak langsung (indirect control) ialah pengawasan jarak jauh. Pengawasan ini dilakukan melalui laporan yang disampaikan oleh para bawahan. Laporan itu dapat berbentuk sebagai berikut (a) tertulis, (b) lisan. Kelemahan dari pada pengawasan tidak langsung itu ialah bahwa sering para bawahan hanya melaporkan hal-hal yang positif saja. Dengan perkataan lain, para bawahan itu mempunyai kecenderungan hanya melaporkan hal-hal yang diduganya akan menyenangkan pimpinan.

Adapun variabel kinerja diukuroleh Prawirosentono (1999:27) mengungkapkan bahwa, "Faktor-faktor yang dijadikan ukuran kinerja adalah (1) Efektivitas (2) Otoritas dan Tanggungjawab (3) Disiplin (4) Inisiatif'. Sedangkan variabel pelayanan diukur oleh Sabarguna (2004:38) yang memberikan kriteria tentang mutu pelayanan yang baik, yakni terdiri atas : “(1) tersedia dan terjangkau (2) tepat kebutuhan (3) tepat sumber daya (4) tepat standar profesi / etika profesi (5) wajar dan aman (6) mutu memuaskan bagi pasien yang dilayani’. Adapun yang menghubungkan variabel pengawasan dan kinerja berdasarkan pendapat yang dikemukakan oleh Harahap (2000:36) merumuskan pengawasan dengan mengungkan bahwa, "pengawasan dapat dirumuskan sebagai ERMC yaitu Expectation (tujuan atau standar), Recording (Pencatatan kinerja), Monitoring (perbandingan antara Expectation dan catatan), dan Correction (tindakan koreksi terhadap penyimpangan yang ada)". Demikian pula yang menghubungkan variabel kinerja dan pelayanan berdasarkan pendapat yang dikemukakan oleh Dwiyanto (1995:6) mengungkapkan bahwa, "Kinerja organisasi publik dapat dikaji dari lima ukuran, yaitu (1) Produktivitas (2) Kualitas layanan (3) responsivitas (4) responsibilitas (5) akuntabilitas".

\section{METODE}

Penelitian ini merupakan penelitian menggunakan metode kuantitatif yaitu penelitian yang ingin mencari jawaban secara mendasar tentang sebab akibat, dengan menganalisa faktor-faktor penyebab terjadinya atau pun munculnya suatu fenomena tertentu. Dengan demikian, dari hasil penelitian ini diharapkan akan dapat memperoleh gambaran yang jelas, sistematis dan faktual mengenai aktivitas pengelolaan dan proses pelayanan kesehatan rawat inap yang dilakukan oleh Perawat Rumah Sakit Umum Undata, Perawat Rumah Sakit Umum Anutapura dan Perawat Rumah Sakit Umum Woodward terhadap pasien, sekaligus diharapkan pula akan dapat memperoleh gambaran yang jelas tentang bagaimana proses pengawasan yang dilaksanakan oleh masing-masing pimpinan rumah sakit umum dalam peningkatan pelayanan kesehatan rawat inap di rumah sakit tersebut.

Data yang digunakan dalam penelitian ini adalah data kuantitatif, sebab data yang digunakan merupakan hasil dari skala pengukuran dari hasil jawaban responden pada kuesioner. Namun adanya data wawancara, observasi, dan dokumentasi juga digunakan sebagai data pendukung dari data kuantitatif yang diperoleh di lokasi penelitian. Adapun unit analisisnya bukan pegawai rumah sakit umum secara menyeluruh, namun hanya pegawai rumah sakit umum yang berkaitan dengan pelayanan kesehatan rawat inap, sebab mereka yang mengetahui dan memahami tentang pengawasan dan pelayanan kesehatan rawat inap, sebaliknya bila bagi pegawai rumah sakit umum yang tidak mengetahui dan mengerti tentang pengawasan dan pelayanan kesehatan rawat inap akan mengalami bias datanya. Berdasarkan hal tersebut maka populasi yang menjadi sasaran dalam penelitian ini yang sekaligus menjadi sumber data adalah Pegawai yang berada di Rumah Sakit Umum Undata, Rumah Sakit Umum Anutapura, dan Rumah Sakit Umum Woodward sebanyak 45 orang, serta juga pasien rawat inap di tiga rumah sakit umum tersebut berfungsi sebagai counter information sebanyak 65 orang yang diambil dari berbagai kelas pasien yang dirawat inap.

Pemilihan ketiga rumah sakit umum tersebut didasarkan pada pertimbangan bahwa ketigarumah sakit umum tersebut memiliki sarana dan prasarana pelayanan kesehatan yang lebih memadai di Kota Palu, sedangkan pemilihan pasien rawat inap didasarkan atas pertimbangan bahwa pasien rawat inap memiliki waktu yang lebih lama 
berada di rumah sakit umum, sehingga lebih merasakan pelayanan kesehatan rawat inap yang dilakukan oleh pihak rumah sakit umum. Teknik analisis yang digunakan dalam penelitian ini yakni dengan menggunakan analisis jalur (path analisys), untuk mengetahui besaran pengaruh dari variabel bebas ke variabel antara, kemudian dari variabel antara ke variabel terikat. Kelebihan dengan menggunakan analisis jalur akan dapat menentukan besarnya pengaruh langsung secara relatif dari variabel bebas pada variabel terikat maupun pada variabel antara dan pengaruh lain yang turut mempengaruhi variabel antara dan variabel terikat.

Pengujian validitas dalam penelitian ini dilakukan dengan menghitung distribusi jawaban responden yang selanjutnya diurutkan mulai dari nilai yang terkecil sampai dengan nilai terbesar, kemudian dikelompokkan ke dalam tiga bagian dari bagian yang terkecil, bagian menengah dan bagian yang terbesar. Selanjutnya dihitung jumlah nilai jawaban setiap pertanyaan. Setelah ditemukan bahwa pertanyaan-pertanyaan yang digunakan penelitian valid, maka selanjutnya diuji reliabilitasnya. Uji reliabilitas dimaksudkan untuk mengukur ketepatan, ketelitian serta keakuratan instrumen yang digunakan dalam mengukur variabel penelitian, artinya hasil pengukuran tetap konsisten, meskipun diuji cobakan pada penelitian yang sama dan dengan menggunakan alat ukur yang sama.

Uji reliabilitas ini dilakukan secara internal yakni secara internal reliabilitas instrumen dapat diuji dengan menganalisis konsistensi butir-butir yang ada pada instrumen dengan teknik tertentu.Pengujian reliabilitas dengan internal contigency, dilakukan dengan cara mencobakan instrumen sekali saja, kemudian yang diperoleh dianalisis. Hasil analisis dapat digunakan untuk memprediksi reliabilitas instrumen. Pengujian reliabilitas instrumen dapat dilakukan dengan teknik belah dua dari Spearman Brown (Sugiyono, 2003:278). Penarikan kesimpulan mengenai keeratan hubungan antara variabel $X$ dan variabel $Z$ serta variabel $Y$, sematamata dilakukan dengan koefisien korelasi (r) kurang memberikan keterangan.Untuk itu, perlu dijelaskan dengan analisis determinan.Dalam analisis korelasi terdapat suatu angka yang disebut dengan koefisien determinasi, yang besarnya adalah kuadrat dari koefisien korelasi $\left(r^{2}\right)$. Koefisien ini disebut koefisien penentu, karena varian yang terjadi pada variabel dependen dapat dijelaskan melalui varian yang terjadi pada variabel independen, (Sugiyono, 2003:216).

\section{HASIL DAN PEMBAHASAN}

\section{Pengawasan}

Dari hasil penelitian dilakukan pengujian secara kausalitas pada variabel pengawasan $(\mathrm{X})$ yang terdiri dari sub variabel pengawasan langsung $(\mathrm{X})$ dan pengawasan tidak langsung $(\mathrm{X})$ terhadap variabel kinerja pegawai $(\mathrm{Z})$.
Adapun dari hasil analisis varians regresi diperoleh nilai $\mathrm{F}$ tabel adalah $\mathrm{F}_{[0,05: 2: 43]}=3.215$. Oleh karena nila $\mathrm{F}_{\text {hitung }}>\mathrm{F}_{\text {tabel }}$ , sehingga dapat diartikan bahwa secara bersama-sama sub variabel pengawasan $(\mathrm{X})$ dapat mempengaruhi variabel kinerja pegawai $(Z)$. Sub varibel pengawasan dalam penelitian ini adalah pengawasan langsung (X) dan pengawasan tidak langsung (X). Dari hasil analisis dan perhitungan bahwa hasil pengujian bersifat signifikan, karena dari hasil pengujian koefisien jalur diperoleh keterangan objektif, bahwa koefisien jalur dari pengawasan ke kinerja pegawai, secara statistik adalah $\mathrm{t}_{\text {hitung }}=4.050$ dan $2.759>\mathrm{t}_{\text {tabel }}=2.018$ bermakna artinya nilai thasil hitung $>\mathrm{t}$ tabel, jadi dapat disimpulkan kedua jalur signifikan. Dari struktur jalur juga dapat diketahui pengaruh variabel pengawasan, baik pengawasan yang dilakukan secara langsung sebesar 0,535 dan pengawasan yang dilakukan secara tidak langsung sebesar 0,365. Secara struktur pengaruh pengawasan baik secara langsung dan tidak langsung terhadap kinerja pegawai dapat digambarkan pada struktur jalur seperti berikut ini:

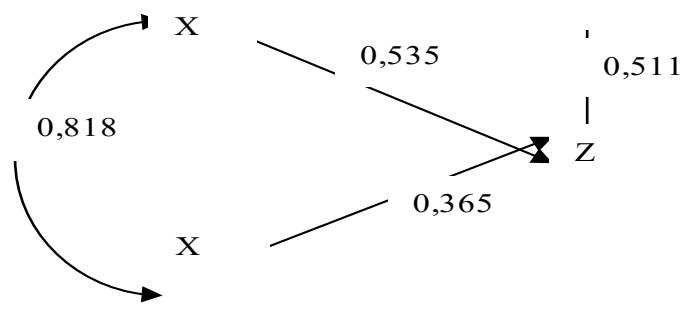

Sumber: Hasil olah data lapangan

Gambar 1. Struktur jalur pengaruh pengawasan langsung dan pengawasan tidak langsung terhadap kinerja pegawai

Sehingga dari hasil tersebut dapat diartikan bahwa pengawasan yang dilakukan oleh pimpinan di Rumah Sakit Umum Undata, Rumah Sakit Umum Anutapura, dan Rumah Sakit Umum Woodward berpengaruh signifikan terhadap kinerja pegawai pada ketiga rumah sakit umum tersebut, akan tetapi memiliki tingkat hubungan yang masih rendah dan sedang, karena besarnya pengaruh langsung dari pengawasan langsung terhadap kinerja pegawai sebesar $0,535 \times 0,535 \times$ $100 \%=28,62 \%$ sedangkan pengaruh langsung dari pelaksanaan pengawasan tidak langsung sebesar $0,365 \mathrm{x}$ $0,365 \times 100 \%=13,32 \%$, pengaruh tidak langsung dari pelaksanaan pengawasan langsung sebesar 0,535 x 0,818 x 0,365 x $100 \%=15,97 \%$ sedangkan dari pelaksanaan pengawasan tidak langsung sebesar $0,365 \times 0,818 \times 0,535$ x $100 \%=15,97 \%$, disisi lain besarnya pengaruh faktor lain terhadap kinerja pegawai memiliki tingkat hubungan yang sedang yakni sebesar $0,511 \times 0,511 \times 100 \%=$ 26,11\%.

Selanjutnya dilakukan pengujian pada variabel kinerja pegawai $(Z)$ yakni seberapa besar variabel kinerja pegawai $(Z)$ berpengaruh terhadap variabel pelayanan kesehatan rawat inap (Y). Setelah diperoleh hasil analisis varians regresi, yang menunjukkan bahwa $\mathrm{F}$ tabel adalah 
$\mathrm{F}_{[0,05: 1: 43]}=4.065$. Oleh karena nila $\mathrm{F}_{\text {hitung }}<\mathrm{F}_{\text {tabel }}$. Sehingga dapat diartikan bahwa variabel kinerja pegawai $(Z)$ tidak dapat mempengaruhi variabel pelayanan kesehatan rawat inap (Y). Dari hasil analisis dan perhitungan tersebut menunjukan bahwa hasil pengujian bersifat tidak signifikan, karena dari hasil pengujian koefisien jalur diperoleh keterangan objektif, bahwa koefisien jalur dari kinerja pegawai ke pelayanan kesehatan rawat inap, secara statistik adalah $\mathrm{t}_{\text {hitung }}=0.234<\mathrm{t}_{\text {tabel }}=2.018$, bermakna artinya nilai $t$ hasil hitung $<\mathrm{t}$ tabel, jadi dapat disimpulkan jalur variabel kinerja pegawai terhadap variabel pelayanan kesehatan rawat inap tidak signifikan. Dari gambar juga dapat diketahui bahwa pengaruh variabel kinerja pegawai terhadap variabel pelayanan kesehatan rawat inap hanya sebesar 0,035 . Secara struktur pengaruh kinerja pegawai terhadap pelayanan kesehatan rawat inap dapat digambarkan pada struktur jalur seperti berikut ini.

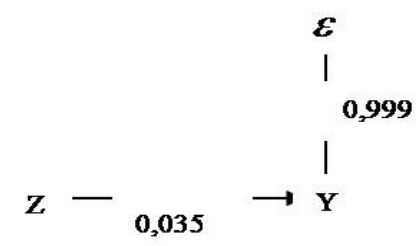

Sumber: Hasil olah data lapangan

Gambar 2. Struktur jalur pengaruh kinerja pegawai terhadap pelayanan kesehatan rawat inap

Dari struktur jalur tersebut dapat diartikan bahwa kinerja pegawai yang berada di Rumah Sakit Umum Undata, Rumah Sakit Umum Anutapura dan Rumah Sakit Umum Woodward tidak memiliki pengaruh signifikan terhadap pelayanan kesehatan rawat inap. Walaupun kinerja pegawai sudah baik, namun pengaruhnya terhadap pelayanan kesehatan rawat inap tidak bersifat signifikan. Karena besarnya pengaruh kinerja pegawai terhadap pelayanan kesehatan rawat inap adalah $(0,035$ x $0,035 \times 100 \%)=0,12 \%$, sedangkan pengaruh faktor lain yang mempengaruhi terhadap pelayanan kesehatan rawat inap memiliki tingkat hubungan yang sangat kuat, yakni sebesar $(0,999 \times 0,999 \times 100 \%)=99,80$ $\%$, dari hal tersebut menandakan bahwa faktor lain lebih mempengaruhi pelayanan kesehatan rawat inap dibandingkan dengan kinerja pegawai.

Berdasarkan kedua sub struktur jalur yang telah diungkapkan di atas, maka secara lengkap struktur jalur sesuai dengan penelitian yang dilakukan dapat disajikan pada gambar berikut ini:

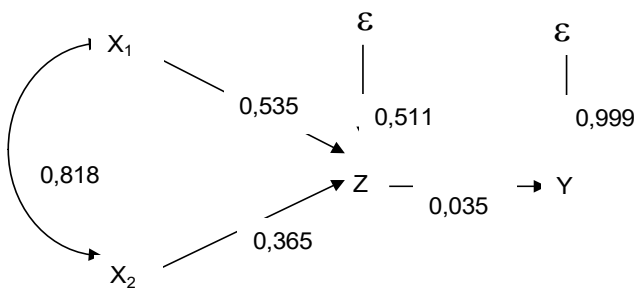

Sumber: Hasil olah data lapangan

Gambar 3. Struktur Jalur Lengkap Hasil Penelitian
Sebagai salah satu cara dalam meningkatkan kinerja pegawai termasuk perawat di rumah sakit adalah dengan melaksanakan pengawasan dengan baik dan terarah, artinya pengawasan dilaksanakan dengan dua cara yakni pengawasan langsung dan pengawasan tidak langsung. Adapun pengawasan langsung dilakukan oleh pimpinan rumah sakit umum agar pimpinan rumah sakit umum secara langsung meninjau para perawat dalam melaksanakan pekerjaannya. Sedangkan pengawasan secara tidak langsung dilakukan untuk melengkapi pelaksanaan pengawasan yang dilakukan secara langsung. Pelaksanaan pengawasan tidak langsung adalah tinjauan hasil pekerjaan administrasi seperti laporan tertulis dan lisan, yang mana hasil dari pengawasan tidak langsung dimaksudkan untuk memperkuat pengawasan langsung. Akan tetapi kelemahan dari pengawasan tidak langsung ini adalah kecenderungan yang dilaporkan hanyalah halhal yang dapat menyenangkan pimpinan rumah sakit umum saja.

Korelasi antara pengawasan langsung dan pengawasan tidak langsung memiliki keterkaitan yang erat dalam pelaksanaan proses pengawasan, artinya dua proses pelaksanaan pengawasan tersebut tidak dapat dipisahkan antara satu dengan lainnya atau dengan kata lain bahwa pimpinan rumah sakit umum tidak dapat melaksanakan secara dominan salah satu dari proses pelaksanaan pengawasan. Karena kedua proses pelaksanaan pengawasan tersebut saling melengkapi antara satu dengan lainnya, sehingga apabila lebih mengedepankan salah satu dari keduanya maka pelaksanaan pengawasan dapat dikatakan cacat atau diperkirakan pengawasan tidak dapat berfungsi dengan baik.

Kegiatan pengawasan yang dilaksanakan oleh pimpinan rumah sakit umum seyogianya akan memberikan dampak positif di lingkungan pekerjaan dan organisasi seperti terciptanya hubungan emosional yang baik antara pimpinan rumah sakit umum dan para perawat, sehingga dengan adanya kedekatan hubungan tersebut akan dapat meringankan beban pekerjaan dan pelaksanaan pekerjaan lebih efektif, disamping itu juga pimpinan rumah sakit umum akan dapat mengetahui permasalahan ataupun kendala yang dihadapi oleh para perawat dalam pelaksanaan tugas, sekaligus juga akan mengetahui sejauhmana pekerjaan yang dilakukan oleh para perawat, serta prestasi kerja yang telah dihasilkan oleh para perawat.

Oleh karena itu, efektivitas pengawasan sangat ditentukan oleh kualitas pimpinan rumah sakit umum. Kedudukan pimpinan rumah sakit umum merupakan seorang pimpinan organisasi yang kompetibel dan memiliki pandangan jauh ke depan, dengan memperhatikan perkembangan zaman yang terus berubah dengan mempengaruhi perubahan pola kerja organisasi yang dipimpinnya, serta dapat berkedudukan sebagai pengayom dan pembina bawahan yang baik, dan mampu 
berpikir secara menyeluruh maupun konseptual sehingga mampu berpikir bagi sistem karir sekaligus penghargaan prestasi kerja perawat yang berada di rumah sakit umum.

\section{Kinerja Pegawai dan Pelayanan Kesehatan}

Kenyataan bila masih terdapat kinerja perawat yang belum melaksanakan pelayanan kesehatan rawat inap yang baik, sehingga pelayanan kesehatan rawat inap dirasakan masih kurang memuaskan pasien memang perlu untuk dicermati, bahwa pada kenyataannya para perawat yang bertugas di rumah sakit umum bukan saja mengerjakan secara spesifik pelayanan kesehatan rawat inap pada pasien, namun para perawat juga mengerjakan berbagai pekerjaan diluar tugas utama mereka, seperti melakukan kebersihan ruangan (cleaning service) yang seharusnya menjadi tugas bagi petugas kebersihan rumah sakit umum, dan juga melaksanakan kegiatan administrasi, untuk kegiatan administrasi memang sudah semestinya menjadi tugas perawat, akan tetapi dengan kurangnya tenaga perawat yang bertugas terkadang tugas administrasi agak terbengkalai. Disinilah kerumitan pelaksanaan tugas perawat dimana harus menyelesaikan tugas-tugas administrasi maupun laporan serta pada waktu yang hampir bersamaan harus segera melakukan tindakan pelayanan kesehatan pada pasien.

Disamping itu, status kepegawaian bagi para perawat yang bertugas di bagian rawat inap terasa kurang mendukung untuk tercapainya pelayanan kesehatan rawat inap yang baik, misanya saja dengan status perawat yang masih sebagai tenaga honorer, bahkan ada perawat yang status kepegawaiannya sebagai tenaga sukarela, ataupun dengan status sebagai perawat kontrak yang mendapatkan gaji masih kurang layak untuk pekerjaan yang penuh dengan resiko dan tanggung jawab yang besar. Oleh sebab itu status kepegawaian perawat yang masih belum jelas juga sedikit banyak turut mempengaruhi kinerjanya.

Perawat yang bertugas dengan status kepegawaiannya belum sebagai pegawai tetap, tentunya hal tersebut secara spikis menjadi pemicu minimnya kinerja mereka, kurangnya kinerja perawat juga didukung oleh masih kurangnya kesejahteraan perawat, serta masih lambannya informasi yang diperoleh mengenai dunia kesehatan khususnya mengenai keperawatan yang sangat penting dalam pengembangan kemampuan melaksanakan tugas. Jumlah tenaga perawat yang masih kurang juga menjadi faktor penyebab masih rendahnya kinerja perawat yang ada di rumah sakit umum, sehingga jumlah para perawat tidak sebanding dengan pekerjaan yang dilakukan, dimana frekuensi pekerjaan yang dilakukan lebih banyak dari jumlah perawat yang ada.

Permasalahan tersebut akan dapat teratasi jika setiap perawat dengan kondisi yang masih serba kekurangan tetap memiliki komitmen yang kuat untuk memelihara eksistensinya sebagai pekerja yang profesional dengan dorongan kemanusian, serta penghayatan terhadap nilainilai profesi perawat itu sendiri dan penghargaan terhadap hak pasien sebagai manusia hamba Tuhan yang harus dihargai, yang dibarengi dengan kepedulian, ketulusan, dan keikhlasan dalam memberikan pelayanan kesehatan rawat inap yang terbaik.

\section{SIMPULAN}

Pengawasan yang dilaksanakan pimpinan rumah sakit umum merupakan suatu hal yang penting, selain pelaksanaan perencanaan, menggerakkan dan organisasi. Pelaksanaan pengawasan merupakan upaya untuk mencapai tujuan yang telah direncanakan, sebab antara perencanaan dan pengawasan merupakan dua hal yang penting bagi organisasi. Disamping itu, pengawasan merupakan upaya menselaraskan seluruh sumber daya yang ada dalam organisasi rumah sakit umum.

Disisi lain pengawasan berpengaruh positif terhadap kinerja pegawai, hal ini menandakan bahwa pengawasan merupakan salah satu cara bagi pimpinan rumah sakit umum dalam meningkatkan kinerja perawat, sebab saat pelaksanaan pengawasan terdapat kontak langsung antara pimpinan rumah sakit umum dan para pegawai, sehingga pimpinan rumah sakit umum dapat mengetahui secara langsung pekerjaan para pegawai serta pencapaiannya. Disamping itu pengawasan diperlukan menurutkebutuhan keadaan dan kebaikan kerja, sehingga pelaksanaan pengawasan dari pimpinan rumah sakit umum menjadi penting karena memiliki efek psikologis yang besar bagi para pegawai dalam melaksanakan pekerjaanya.

Pelaksanaan pengawasan dapat dilakukan secara langsung dan dapat pula dilakukan secara tidak langsung. Kedua pelaksanaan pengawasan tersebut adalah dua komponen yang tidak bisa dipisahkan antara satu dengan lainnya, dengan kata lain bahwa pelaksanaan pengawasan tidak dapat dilakukan secara dominan satu hal saja, sebab ke dua komponen pengawasan tersebut saling melengkapi antara satu dengan yang lainnya, yakni hasil pengawasan tidak langsung dapat dilengkapi dengan pengawasan langsung, demikian pula sebaliknya. Pengawasan yang baik adalah pengawasan yang dapat melaksanakan dua komponen sekaligus yakni pengawasan langsung dan pengawasan tidak langsung, sehingga bila salah satu komponen pengawasan tidak dapat dilaksanakan dengan sebaik-baiknya maka pengawasan tidak berfungsi dengan optimal.

Adapun kinerja pegawai kurang berpengaruh terhadap pelayanan kesehatan rawat inap. Hal ini disebabkan kurangnya tenaga pegawai atau perawat yang berada di rumah sakit umum,serta frekuensi pekerjaan para perawat lebih banyak dari jumlah perawat itu sendiri. Disamping itu, berbagai faktor lain juga turut mempengaruhi kurang maksimalnya kinerja perawat, seperti status kepegawaian perawat, kesejahteraan dan gaji yang masih perlu untuk diperbaharui kembali, sehingga kondisi tersebut akan berdampak pada pelaksanaan pelayanan kesehatan rawat inap. 


\section{DAFTAR PUSTAKA}

Dwiyanto, A. (1995). Penilaian Kinerja Organisasi Pelayanan Publik, Yogyakarta: Fisipol UGM.

(2002). Reformasi Birokrasi Publik Di Indonesia, Pusat Studi Kependudukan dan Kebijakan, Yogyakarta: Universitas Gadjah Mada.

Harahap, S.S. (2000). Sistem Pengawasan Manajemen, Jakarta: Pustaka Quantum.

Napitupulu, P. (2007). Pelayanan Publik dan Customer Statisfiction. Bandung: PT. Alumni.

Ndraha, T. (2008). Kybernologi (Ilmu Pemerintahan Baru). Jakarta : Bineka Cipta.
Prawirosentono, S. (1999). Kebijakan Kinerja Karyawan, Yogyakarta: BPFE.

Sabarguna, H. dan Boy S. (2004). Manajemen Operasional Rumah Sakit, Yogyakarta: Konsorsium Rumah Sakit Islam Jateng - DIY.

Siagian, S.P. (1989). Filsafat Administrasi, Jakarta: Haji Masagung.

Sugiyono. (2001). Metode Penelitian Administrasi, Bandung: Alfabeta.

(2003). Statistika Untuk Penelitian, Bandung: Alfabeta 